\title{
SISTEM AKUNTANSI BELANJA MODAL PADA BADAN KEUANGAN DAERAH KABUPATEN BULELENG
}

\author{
Anak Agung Istri Intan Rusmarini \\ Jurusan Akuntansi Program Diploma III, \\ Universitas Pendidikan Ganesha, Singaraja \\ e-mail : Agungintan55@gmail.com
}

\begin{abstract}
Abstrak
Penelitian ini bertujuan untuk mengetahui Sistem Akuntansi Belanja Modal pada Badan Keuangan Daerah Kabupaten Buleleng. Metode yang digunkanan deskriptif kualitatif. Jenis data yang digunakan adalah data kualitatif. Dengan sumber data yaitu data primer dan sekunder, sedangkan metode pengumpulan data menggunakan metode dokumentasi dan wawancara. Selanjutnya data diolah menggunakan metode analisis deskriptif kualitatif.

Hasil penelitian menunjukkan bahwa pelaksanaan sistem akuntansi belanja modal pada Badan Keuangan Daerah Kabupaten Buleleng sudah dilaksanakan dengan baik dan mengikuti peraturan-peraturan sesuai dengan peraturan Bupati Buleleng. Dokumen yang terkait dalam pelaksanaan sistem akuntansi belanja modal meliputi Surat Pencairan Dana (SP2D), Surat Perintah Pembayaran (SPP), Surat Perintah Membayar (SPM), Surat Penyediaan Dana (SPD).
\end{abstract}

Kata Kunci : Sistem akuntansi, Belanja modal

\begin{abstract}
This study aims to determine the Capital Expenditure Accounting System at the Regional Finance Agency of Buleleng Regency.

This study used descriptive qualitative method. The type of data used is qualitative data. The subject of this research is the Regional Finance Board of Buleleng Regency and the object of this research is capital expenditure system in capital of Buleleng. With the data source that is primary and secondary data, while data collection method using documentation and interview method. Further data is processed using descriptive qualitative analysis method.

The results showed that the implementation of capital expenditure accounting system at the Regional Finance Agency of Buleleng Regency has been implemented well and followed the regulations in accordance with the regulation of Buleleng Regent. Related documents in the implementation of the capital expenditure accounting system include the Fund Disbursement Letter (SP2D), Payment Order Letter (SPP), Payment Order (SPM), Letter of Provision of Funds (SPD).
\end{abstract}

Keywords : Accounting system, Capital expenditure 


\section{Pendahuluan}

Sistem Informasi Akuntansi merupakan sistem informasi fungsional yang mendasari sistem informasi fungsional yang lainnya seperti sistem informasi keuangan, sistem informasi pemasaran, sistem informasi produksi dan sistem informasi sumber daya manusia. Sistemsistem informasi lain membutuhkan data keuangan dari sistem informasi akuntansi.

Sistem informasi akuntansi sangat berperan penting bagi berbagai pihak dalam menyajikan informasi yang diperlukan, baik itu organisasi yang berorientasi mencari keuntungan maupun organisasi yang tidak berorientasi mencari keuntungan (nirlaba). Banyak organisasi yang memerlukan informasi akuntasi dalam mengambil keputusan, yang memerlukan informasi akuntasi adalah investor, kreditur usaha, masyarakat dan juga pemerintah. Pemerintah sangat memerlukan informasi akuntansi dalam menyusun anggaran pemerintah berikut segala anggaran menggunakan informasi akuntasi.

Sistem Akuntansi Pemerintahan merupakan serangkaian prosedur manual atau yang terkomputerisasi mulai dari pengumpulan data, pencatatan, pengikhtisaran dan pelaporan posisi keuangan dan operasi keuangan pemerintah. Sistem akuntansi pemerintahan harus dirancang sesuai dengan konstitusi dan peraturan perundang-undangan yang berlaku pada suatu negara. Sistem akuntansi pemerintahan harus dapat menyediakan informasi yang akuntabel dan auditable.

Belanja pada pemerintah daerah sudah ditentukan anggarannya dalam APBD untuk membiayai kegiatan-kegiatan dan proyek - proyek daerah selama satu tahun anggaran. Belanja di lingkungan akuntansi pemerintahan di Indonesia diartikan sebagai semua pengeluaran dari Rekening Kas Umum Negara/Daerah yang mengurangi ekuitas dana lancar dalam periode tahun anggaran bersangkutan yang tidak akan diperoleh pembayarannya kembali oleh pemerintah.

Badan Keuangan Daerah Kabupaten Buleleng sebagai Bendahra Umum Daerah yang mengelola keuangan daerah menerapkan Sistem Akuntansi berbasis Akrual untuk melaksanakan pengelolaan keuangan daerah.

\section{Metode Penelitian}

Penelitian ini pada Badan Keuangan Daerah Kabupaten Buleleng, kemudian dilakukannya observasi awal pada lokasi penelitian, dari proses observasi tersebut maka ditetapkan rumusan masalah, kemudian untuk menjawab rumusan masalah yang telah dibuat tersebut, maka akan dicari kajian teori yang sesuai dengan masalah yang diangkat. Metode yang digunakan dalam proses pengumpulan data yaitu dengan menggunakan metode wawancara dan metode dokumentasi.

Data-data yang nantinya diperoleh akan mengalami suatu renovasi yang disebut dengan pengolahan data. Pengolahan data yang dilakukan menggunakan tekhnik analisis deskriptif kualitatif yaitu mengolah data dengan lebih banyak mengumpulkan data berupa keterangan atau informasi yang tidak berbentuk angka sehingga akan diperoleh suatu hasil dari pengolahan data yang disebut dengan hasil penelitian. Hasil penelitian yang telah diperoleh tersebut merupakan jawaban atas permasalahan yang sedang diteliti penulis dan dari hasil penelitian ini pun penulis dapat menaik suatu kesimpulan.

\section{Hasil dan Pembahasan}

Sistem Akuntansi Belanja Modal merupakan sistem belanja yang dimana setiap kegiatan sudah dibuatkan anggaran dalam APBD. Belanja modal pada Badan Keuangan Daerah Kabupaten Buleleng adalah belanja modal yang digunakan untuk keperluan instansi. Akuntansi belanja pada BKD meliputi akuntansi belanja UP (Uang Persediaan)/GU (Ganti Uang)/TU (Tambah Uang), dan akuntansi belanja LS (Langsung).

Hasil penelitian mengenai sistem belanja modal pada Badan Keuangan Daerah Kabupaten Buleleng dapat dilihat melalui Peraturan Pemerintah atau Peraturan Bupati mengenai tata cara pelaksanaan anggaran pendapatan dan belanja daerah tahun anggaran.

Berdasarkan Peraturan Bupati Kabupaten Buleleng, maka sistem akuntansi belanja modal yang dilaksanakan pada BKD Kabupaten Buleleng adalah sebagai berikut : 
1. SKPD menyusun RKA (Rencana Kerja Anggaran)

2. Apabila RKA disetujui akan dikeluarkan (DPA) Dokumen Pelaksanaan Anggaran. Dari DPA yang sudah di otorisasi oleh BUD, maka diterbitkan SPD yang ditujukan kepada pengguna anggaran.

3. Pejabat Pelaksana teknis kegiatan mengajukan SPP (Surat Perintah Pembayaran) melalui (PPTK) pejabat penatausahaan keuangan pada SKPD kepada pengguna anggara/kuasa pengguna anggaran setelah diterimanya tagihan dari pihak ketiga.

4. Pengajuan SPP dilampiri dengan kelengkapan persyaratan yang ditetapkan sesuai dengan peraturan perundang-undangan.

5. Dalam hal SPP yang diajukan dinyatakan lengkap dan sah, maka pengguna anggaran atau kuasa pengguna anggaran menerbitkan SPM.

6. Dalam hal SPP yang diajukan dinyatakan tidak lengkap dan/atau tidak sah, pengguna anggaran atau kuasa pengguna anggaran menolak menerbitkan SPM.

7. Kuasa BUD meneliti kelengkapan SPM (Surat Perintah Membayar) yang diajukan oleh pengguna anggaran/kuasa pengguna anggaran agar pengeluaran yang diajukan tidak melampaui pagu dan didukung dengan kelengkapan dokumen sesuai ketentuan yang berlaku.

8. SPM yang telah diterbitkan sebagaimana dimaksud diajukan kepada kuasa BUD untuk penerbitan SP2D (Surat Perintah Pencairan Dana).

9. SP2D yang diterbitkan oleh BUD/Kuasa BUD dicairkan dengan memindahbukukan dari rekening Kas Daerah ke rekening penerimaan. Pembayaran belanja ini menggunakan mekanisme pembayaran langsung pada pihak ketiga, maka SP2D langsung ditujukan kepada rekening pihak ketiga.

Dokumen-dokumen yang digunakan dalam sistem akuntansi belanja modal pada Badan Keuangan Daerah Kabupaten Buleleng sudah sesuai dengan peraturan yang berlaku. Dari hasil penelitian ini dokumen yang digunakan berupa Surat Penyediaan Dana (SPD) , dimana SPD ini berupa dokumen yang berisi informasi mengenai tersedianya dana untuk melakukan kegiatan belanja modal. Surat Permintaan Pembayaran atau SPP, dokumen ini berisi tentang rincian belanja modal yang akan dikeluarkan. SPP belanja modal ini berfungsi sebagai rincian rekening, dan rincian sisa dana yang ada pada Kas Daerah. Surat Perintah Membayar atau SPM dikeluarkan jika sudah dilengkapi dengan adanya Surat Penyediaan Dana, Surat PertanggungJawaban, dan Surat Perintah Pembayaran, SPM ini disahkan oleh Kepala Sub/bidang. Surat Perintah Pencairan Dana atau SP2D, Surat Perintah Pencairan Dana diterbitkan oleh bendahara umum pemegang kas daerah pada Badan Keuangan Daerah Kabupaten Buleleng. SP2D dibuat sebagai bukti konkrit untuk pencairan dana dari kas daerah. Surat Perintah Pencairan Dana (SP2D) ini sah apabila telah ditandatangani dan distempel oleh Kepala Badan Keuangan Daerah Kabupaten Buleleng atau pejabat yang berwenang.

\section{Simpulan dan Saran}

Hasil penelitian menunjukkan bahwa pelaksanaan sistem akuntansi belanja modal pada Badan Keuangan Daerah Kabupaten Buleleng sudah dilaksanakan dengan baik dan mengikuti peraturan-peraturan sesuai dengan peraturan Bupati Buleleng. Dokumen yang terkait dalam pelaksanaan sistem akuntansi belanja modal meliputi Surat Pencairan Dana (SP2D), Surat Perintah Pembayaran (SPP),Surat Perintah Membayar (SPM), Surat Penyediaan Dana (SPD). 
VOL.6, NO. 2, OKTOBER 2017

p-ISSN : 2337-537X

\section{Daftar Pustaka}

Andasuri Shela, Sistem Akuntansi tersedia pada http://eprints.polsri.ac.id/2500/ (Diakses pada tanggal 24 April 2017)

Ariestya Wiyargi, Sistem Akuntansi tersedia pada http://eprints.uny.ac.id/7721/ (Diakses pada tanggal 24 April 2017)

Livo

Sunarsih,

Pengertian

Sistem

Informasi

tersedia pada http://livooz.blogspot.co.id/2013/03/pengertian-sistem-informasimenurut.html (Diakses pada tanggal 24 April 2017)

Mandar

Trisno

Hadisaputro,

Belanja

Modal

tersedia

pada

http://www.mudjisantosa.net/2012/07/belanja-barang-dan-belanjamodal.html

(Diakses pada tanggal 24 April 2017)

Merystika Kabuhung, Unsur-unsur Sistem Akuntansi tersedia pada

https://ejournal.unsrat.ac.id/index.php/emba/article/view/1832 (Diakses pada tanggal 24 April 2017)

Nur

Azizah

Belanja

Daerah

tersedia

pada https://www.academia.edu/17233236/Makalah Belanja Daerah Studi Kasus Bela nja Pegawai Ngawi (Diakses pada tanggal 24 April 2017)

Nur Fadhila Amri, Akuntansi Sektor Publik tersedia pada http://www.eakuntansi.com/2015/09/belanja-modal.html (Diakses pada tanggal 24 April 2017)

Nurul Fitri Hasanah, Pengertian Sistem Akuntansi tersedia pada http://eprints.uny.ac.id/9016/(Diakses pada tanggal 24 April 2017)

OE

Hutapea,

Pengertian

Sistem

tersedia

pada

http://repository.widyatama.ac.id/xmlui/handle/123456789/3788 (Diakses pada tanggal 24 April 2017)

Syukriy, Belanja Modal dan Perubahan APBD tersedia pada https://syukriy.wordpress.com/2013/11/01/belanja-modal-dan-perubahan-apbd/ (Diakses pada tanggal 24 April 2017) 